
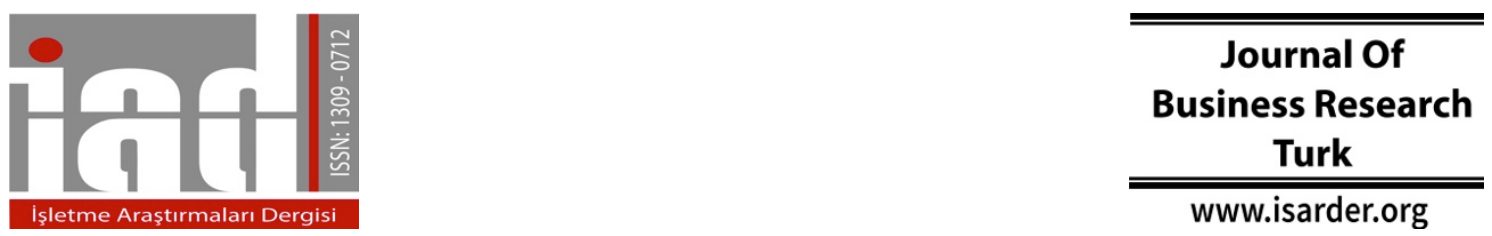

\title{
A New Model for Customer Equity
}

\author{
Pelin OZGEN \\ At1lım University \\ Faculty of Management \\ 06830 Incek, Ankara, Turkey \\ orcid.org/0000-0002-0483-5457 \\ pelin.ozgen@atilim.edu.tr
}

\begin{abstract}
In this study, the fundamental model of customer equity is studied and an alternative model is tested where attitudinal and behavioral customer loyalty are treated as two additional individual components of customer equity. In gathering required data, survey method is used with 377 respondents based on judgement sampling. In order to test the proposed model, a different calculation for customer equity is applied. In model testing, LISREL package program is used and structural equation modelling (SEM) is applied. Results indicate that the proposed model stating that customer equity, has two more components, namely attitudinal loyalty and behavioral loyalty, is significant at $95 \%$ confidence level, has a high goodness of fit $(\mathrm{GFI}=.93)$ and has an acceptable level of root mean square error $(\mathrm{RMSEA}=.07)$. However, results also show a correlation between value equity and brand equity terms, which can be tested with different products or sample in future studies.
\end{abstract}

Keywords: Customer Equity, Customer Lifetime Value, Attitudinal Loyalty, Behavioral Loyalty

\section{Introduction}

Firms are currently faced with a trend towards individualization and customization in all areas of business as "millennials" and "post-millennials" constitute a larger market every day. Consequently, "marketing concept", which focuses on a target segment of consumer needs and wants, has evolved to "customer concept", in which the needs and wants of individual customer is emphasized (Hoekstra, Leeflang and Wittink, 1999). With the increased importance of individual customer, his/her individual value to the firm has become a significant research topic (Bayon, Gutsche, and Bauer, 2002; Hansotia, 2004; Kumar, Lemon and Parasuraman, 2006; Rust, et.al, 2004). Consequently, in an environment where importance of the customer has enormously increased, the emphasis on "brand equity" is now replaced by the concept of "customer equity" term.

Customer equity is basically an extended version of "customer lifetime value (CLV)" and is defined as the sum of present value of all existing and potential 
customers of the company in their total lifetime (Blattberg and Deighton, 1996). Customer equity is accepted to have three components, namely value equity, brand equity and relationship equity. Yet, researchers are unanimous that more research should be carried out about the value of the customer to the firm (Thomas, Reinartz and Kumar, 2004, Dorsch et.al. 2001, Peppers and Rogers, 2005; Villanueva and Hanssens, 2007). In an attempt to contribute to the current research in the literature, in this study, the customer equity concept, which is a revolutionary paradigm that makes companies focus on individuals rather than on groups or masses, is studied and the shortcomings of the model is discussed, which is followed by testing the proposed model. In the proposed model, attitudinal and behavioral loyalty terms are superimposed to the model as two individual terms. Finally, the results and the recommendations for further studies are presented.

\section{Customer Equity}

\subsection{CLV and Customer Equity Concept}

CLV models were first proposed in the direct marketing arena (Dwyer, Schurr and Oh, 1987), where the necessary data on individual-level marketing interventions and profitability were readily available. These concepts were soon applied also in financial services (Storbacka, Strandvik and Grönroos, 1994). A comprehensive overview of available CLV models is given in Berger and Nasr (1998) based on the ability to accurately estimate customer profitability (Mulhern, 1999).

The CLV concept was extended to the concept of customer equity (the sum of the firm's customers' CLVs), enabling CLV to be used to guide corporate strategy (Blattberg and Deighton 1996, Blattberg, Getz and Thomas, 2001, Fruchter and Zhang 2004, Thomas, Blattberg and Fox, 2004, Pfeifer and Carraway 2000). These models (see also) were based on firms that had a customer database, and did not incorporate the effect of competition. Econometric models for projecting the CLV, based on customer databases, have been developed (e.g., Reinartz and Kumar 2002, 2003). By combining the customer equity idea with the chain of effect models for return on quality, and collecting data necessary to analyze the impact of competition, it is possible to create a model that can project the impact on customer equity of any marketing expenditure (Rust et al. 2000, 2004). Subsequent authors have explored a variety of aspects related to the implementation of customer equity management in practice (Bell et al. 2002, Berger et al. 2002, Hogan, Lemon and Rust, 2002, Rust et al. 2004).

\subsection{Customer Equity Model and Components of Customer Equity}

According to the most accepted model in literature on customer equity concept is created by Rust, Zeithaml and Lemon (2000). In this model, the researchers suggest that, customer equity is composed of three components, which are named as value equity, brand equity and relationship/retention equity.

Value equity is regarded as objective evaluations of the customers about the firm's products and is affected by evaluations about quality, convenience and price (Rust, et.al.2000).

Brand equity is defined as "the value that brand name alone adds to the value of the product" (Leuthesser, Kohli and Harich, 1995; Aaker, 1992). According to the creators of customer equity concept, brand equity is composed of 3 sub-factors, which 
are brand awareness, brand positioning and brand ethics (Rust et.al, 2001, Rust et.al 2004 (b), Leone et.al. 2006). These are all based on the perceptions of the customers. Therefore, brand equity forms as a result of all subjective and emotional evaluations by the customer.

Relationship/retention equity is the third component of customer equity and it represents the subjective evaluations of the customer, about the relationship between the company and himself. Based on the strength of that relation the customer stays with the company. Relationship equity has 5 subcomponents namely loyalty programs, special recognition and treatment, affinity and emotional connection programs, user group programs and informative programs.

The original model of customer equity and its components are shown in figure 1:

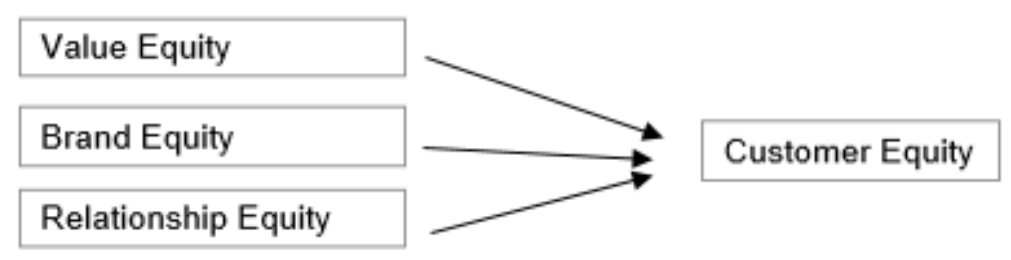

Figure 1: Components of Customer Equity

\subsection{Benefits of Using the Customer Equity Approach}

The founders of the customer equity approach, Rust, Zeithaml and Lemon (2000) suggest that with the use of the approach, the financial value of the customers that the company has can be digitized and decisions about acquiring new customers, customer retention and the expenses needed to make cross-selling can be made on the basis of more data. Moreover, with the use of this method, not only the levels of marketing expenses throughout the customer life cycle can be determined but also the customers with a larger potential of lifetime value can be identified, leading to a better targeted market selection. In other words, provided that the customer equity approach is used, how much value an average customer has for the company in each market segment can be known, and thus, it would be possible to calculate the return on the investment (ROI) made in customers and to evaluate the quality of investments.

\section{Customer Loyalty}

Dick and Basu (1994), who are the most cited researchers in the literature on customer loyalty concept, define it as "the relative attitude of the customer to the product and the repetitive purchasing behavior" and also tried to classify the concept, and emphasized that the customer loyalty has cognitive, emotional and behavioral components. Furthermore, authors state that it will be a more accurate description to define loyalty as a combination of attitudes and behaviours.

Behavioral Loyalty: Zeithaml and Bitner (1996) argue that customer loyalty is "the frequency of being a customer for a product, constantly choosing the same goods and services or a company".

Therefore, behavioural loyalty can be evaluated by using the customer's purchase intentions that result in behaviour or, in other words, the purchasing frequency (Chang and Chen, 2006). However, behavioural loyalty maybe misleading, since there 
is no distinctive difference between behavioural loyalty and repeat purchase behavior (Day, 1969).

The most important property that lacks in behavioral loyalty approach is that, in this approach, researchers focus on which product is bought, where and how much is bought instead of seeking an answer to the question of "why". In other words, the most important question which enables to reveal the motives that lead to purchasing behaviour is missed.

To sum it up, although behavioural loyalty is a necessary condition for a company to generate profit, it cannot guarantee that the customer will stick to that brand in the future. Therefore, the repurchase of the customer does not always mean commitment and loyalty (Bowen and Chen, 2001) and attitudes should also be taken into account.

Attitudinal Loyalty: Attitudinal customer loyalty was proposed by Day (1969) for the first time. Unlike behavioural loyalty, it is defined as an approach in which attitudinal data are used to express the psychological and emotional commitment of a customer to a brand (Degermen 2006). Jacoby and Kryner (1973) emphasise that there should be a difference between the customer who purchases a brand only due to convenience and the customer who really prefers and purchases that brand. Other researchers such as Reinartz and Kumar, (2002), Kim et al. (2007), Keiningham, et.al. (2006) and, Baloğlu (2002) also stated that it would be wrong to evaluate repetitive purchasing behavior as customer loyalty and attitudes play a big role in the formation of loyalty. For this reason, companies' efforts to establish an emotional bond with customers rather than concrete benefits are attracting attention in their promotional studies (Graeff, 1996).

While the measurement of loyalty is performed with purchasing amount and frequency in behavioural loyalty, in the measurement of attitudinal loyalty, customer's preferences, commitment or purchase intentions should be measured.

Mixed Approach: The aforementioned two dimensions are integrated into mixed approach by Dick and Basu (1994), where brand loyalty of customers is measured with the help of factors including both attitudinal and behavioral elements such as customers' product preferences, brand loyalty tendencies, percentage of purchases, new purchases and total purchase amount. According to this approach, it is important to use the attitude and behavioural approach together in a satisficing definition of a loyalty. In this context, Kim et al. (2004) define customer loyalty as "the combination of consumers' positive attitude towards the brand and re-purchasing behaviour". In other words, despite the fact that it is the behaviour of customers which is important in short term; it is observed that in the long term, attitudinal loyalty is more profitable for companies rather than behavioural loyalty.

\section{Measurement of Customer Equity}

Studies on the calculation of the customer lifetime value can be grouped under four main headings as basic structural model, direct marketing/customer relationship management models, new customer acquisition and customer retention model, and customer migration model. 


\subsection{Basic Structural Model}

In this model, it is assumed that cash flows always occur at the end of the period, past customers or potential customers are ignored and only the current active customers of the firm are taken into account and acquisition costs are not used in calculations (Berger and Nasr, 1998). This is the simplest version of all calculation methods.

\subsection{Direct Marketing / Customer Relationship Management Models}

According to this model, companies keep the marketing expenses they have made for certain customers and the customer's purchases in their databases, and the lifetime values of customers can be easily calculated in this way (Rust and Verhoef (2005)).

\subsection{Customer Acquisition and Customer Retention Model}

As mentioned previously, customer acquisition and retention have a great importance in customer equity (Hansotia, 2004) since acquisition or retention actions are accepted as the response variables to marketing activities. Thus, the customer equity model, which is also known as "the decision calculus model" developed by Blattberg and Deighton (1996) uses the new customer acquisition and retaining existing customers. By this way, an effective management of the customer portfolio and calculation of the return of marketing investments (ROMI) are ensured (Brocco, 2004).

In this model, it is necessary to be able to manage the customer's life cycle and to optimise the amount of new customer acquisition, customer retention and cross-selling expenses in order to be able to evaluate customer equity as a financial asset. However, to do these, it is assumed that there is a database containing customer behaviours and all the relationships established between the customer and the company over time.

\subsection{Customer Migration Model}

In the other models for the customer lifetime value and customer equity mentioned above, calculations begin with an analysis of the company's existing customer base and customer retention ratios. Furthermore, when customers stop purchasing from the company, it is thought that customers will not make a purchase from the same company again, and be lost forever. However, it has been observed that this assumption has led the less calculation of the customer lifetime value by $47 \%$ less than actual value (Rust et al., 2005). Therefore, the "customer migration model" was developed by Dwyer (1997). In this model, customers are divided into two as "those who always have a share" and "those who have been completely lost". Moreover, the data of the last purchasing time (recency) are used for the estimation of customers' purchasing behaviours. Thus, customers' purchasing tendencies for the future are calculated based on their past purchases.

The most important advantage of Dwyer's model (1997) over the basic structural model and decision calculus model is that the customer purchasing probabilities are included in the model. Therefore, the customer migration model seems more realistic. On the other hand, the fact that purchasing period is calculated to have fixed intervals and that cash flows are accepted to be realised in the same period along with the realisation of sales are the disadvantages of the model (Jain and Singh, 2002). 


\section{Alternative Suggestion for Measurement}

In previous studies, it is observed that researchers have reduced the calculations by making various assumptions when they have studied with databases of companies comprising for long years. However, since it was not possible to reach such a rich data, in this study, the start was given with the definition of customer equity on the basis of selected examples of brands, based on the definition of the concept the size of the customer equity was calculated.

As it can be remembered, customer equity is defined as "the present value of the sum of the lifetime values of all existing and potential customers of the company" (Blattberg and Deighton, 1996) and can be increased by customer development through new customer acquisition, retention of current customers or cross-selling to the existing customers. Therefore, it may be possible to reach an indicator of the customer equity by determining the companies' new customer acquisition ratios and customer retention ratios, how many times the customers have made purchases through a planning horizon on average, and their positive tendency towards to cross-selling.

Based on the discussion above, one important contribution of the study is on calculation of customer equity, which will be explained in detail in the methodology section.

\section{Critics on the Current Model of Customer Equity}

Mellens, Dekimpe and Steenkamp (1996) state that it is not sufficient to measure the purchasing tendencies of customers to be able to talk about attitudinal customer loyalty that can turn into profitability for the company, and that the factors of performing the brand's advocacy and word of mouth by these people should also be examined. It is observed that especially the behavioural aspect has a strong influence on the loyalty behaviour measured within the components in the customer equity model developed by Rust et al (2004), and this may indicate a fake loyalty due to inconveniences mentioned previously. Therefore, it is necessary to include attitudinal and emotional components in loyalty measurements (Keiningham et al., 2006)

In the accepted model, brand equity, as the second component of customer equity, is defined as "the value perceived by customers using the product only because of the brand name- beyond the concrete benefit of the product". According to previous studies on brand equity, it is observed that studies are carried out in three categories under the names of consumer-based, financial and mixed approaches. However, the definition accepted in the customer equity model is apart from the brand equity definitions in the literature.

In the brand equity literature, Aaker's and Keller's studies are accepted to be the fundamentals of the theory and that brand equity is accepted to stem from factors like brand knowledge, brand awareness, brand image, perceived quality, brand associations and other brand assets (Aaker, 1992, Keller, 2001) . In Aaker's model (1996), there is also a component called as "brand loyalty" which makes up brand equity, however, that loyalty mentioned here is only discussed within the frame of the hypothesis that "the customers of brands with a high brand equity will always buy the same brand". In this context, customer loyalty is accepted to be equal with repetitive purchasing behaviour and that no emotional commitment is mentioned. In other words, it can be said that the concept of customer equity that Aaker mentioned within the brand equity was made 
according to the modern definition including the attitudes. As it can be seen from the other studies in the literature (e.g. Srinivasan, Park and Chang, 2005), brand equity affects the brand preference, but attitudes should also be taken into account for being able to talk about precise customer loyalty.

The final critic is on relationship equity. Indeed, it has been stated in the model developed by Rust et al.(2004) that the relationship equity can be increased through loyalty programs, personalised behaviours, the programs that create an emotional bond, the programs that create user groups and the programs that create information. However, it is observed in the studies carried out (e.g. Baloğlu, 2002, Yi and Jeon, 2003) that customers tend to be loyal to activities, not the company through such activities, therefore the risks of moving to other companies engaged in similar activities are not lost. Therefore, it is observed that loyalty programs or similar relation capital programs do not involve the customer loyalty, which has been previously described and has an attitudinal component.

\section{Methodology}

In this study, the concept of customer equity is analyzed. According to the literature, customer equity has three components; value equity, brand equity and relationship equity. However, even though the close relationship of the customer equity term with loyalty is observed, it is seen that attitudinal component of loyalty is mostly disregarded in discussions. Therefore, the purpose of this study is to test an alternative customer equity model in which attitudinal and behavioral customer loyalty are treated as two other individual components of the term. Primary data, gathered from 377 judgmentally selected respondents via survey, is used. In order to test the proposed model, confirmatory factor analysis is applied.

The hypothesis, which is being tested is as follows:

$\mathrm{H}_{1}$ : Customer equity has five distinct components named as value equity, brand equity, relationship equity, attitudinal loyalty and behavioral loyalty.

The proposed model is shown in figure 2:

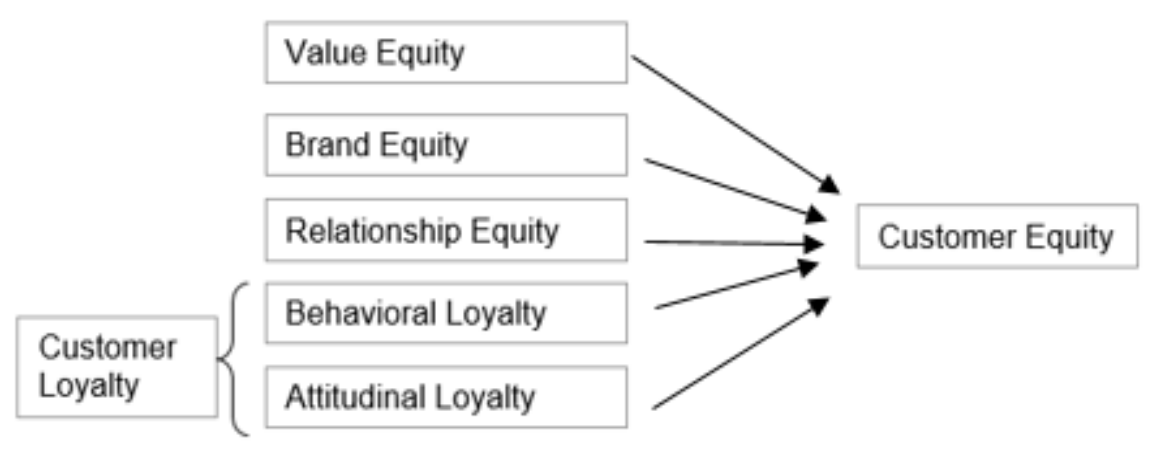

Figure 2: Proposed Model of Customer Equity

In order to test the proposed model LISREL software is used and structural equation modelling (SEM) is applied. As seen in the figure, the customer equity term is accepted as the dependent variable and the components are accepted as the latent variables. 
In gathering the data for testing the proposed model, customer equity is calculated by means of the definition of the term, and based on the customer evaluation of the components. Here, the components of the customer equity are identified with respect to Rust et.al. (2004), and it is seen that customer equity is dependent on customer lifetime value, which can be projected with the data on frequency of purchases, customer acquisition, customer retention and cross selling opportunities.

Questions in the survey, possible answers and how they are going to be used in the calculation are given in the table below (Table 1).

Table 1: Scoring of the components in the customer equity calculation

\begin{tabular}{|l|l|l|l|}
\hline Question & Purpose & $\begin{array}{l}\text { Possible } \\
\text { Answers }\end{array}$ & $\begin{array}{l}\text { How Is It Going To } \\
\text { Be Used In Analysis }\end{array}$ \\
\hline $\begin{array}{l}\text { How Many Times Did } \\
\text { You Buy From This } \\
\text { Brand Within Last 5 } \\
\text { Years? }\end{array}$ & $\begin{array}{l}\text { To Find Out } \\
\text { Purchase } \\
\text { Frequency }\end{array}$ & Any Number & Used As Is \\
\hline $\begin{array}{l}\text { Previous Brand Same } \\
\text { Or Different? }\end{array}$ & $\begin{array}{l}\text { To See Customer } \\
\text { Acquisition }\end{array}$ & Yes/No & $\begin{array}{l}\text { Yes =0 Points } \\
\text { No=1 Points }\end{array}$ \\
\hline $\begin{array}{l}\text { Are You Planning To } \\
\text { Buy From The Same } \\
\text { Brand The Next Time? }\end{array}$ & $\begin{array}{l}\text { To See Customer } \\
\text { Retention }\end{array}$ & Yes/Maybe/No & $\begin{array}{l}\text { No=1 } \\
\text { Maybe=2 } \\
\text { Yes=3 }\end{array}$ \\
\hline $\begin{array}{l}\text { Would You Buy Other } \\
\text { Products From The } \\
\text { Same Brand? }\end{array}$ & $\begin{array}{l}\text { To See Cross } \\
\text { Selling Possibility }\end{array}$ & Yes/Maybe/No & $\begin{array}{l}\text { No=1 } \\
\text { Maybe=2 } \\
\text { Yes=3 }\end{array}$ \\
\hline
\end{tabular}

For each respondent, the scores of the corresponding answers are summed up, to be used as an indicator for customer equity. In other words, in this study, the customers purchase behaviors or intentions are used as a cue for customer equity of the brand. This calculation method can be accepted as another contribution to the current literature on the topic.

\section{Results}

The sample used is composed of 377 respondents. With respect to preferred mobile phones, it is seen that 209 (55.4\%) of them use Brand A, and 168 (44.6) use Brand B. It can be said that the distribution of brands is acceptably even. The same applies for gender distribution, where $182(48.3 \%)$ are female and $195(51.7 \%)$ of the respondents are male.

Age distribution of the respondents are given in Table 2.

Table 2: Age distribution of respondents

\begin{tabular}{cccc}
\hline Age & Frequency & $\%$ & Cum. \% \\
\hline $16-24$ & 183 & 48.5 & 48.5 \\
$25-33$ & 88 & 23.3 & 71.9 \\
$34-42$ & 47 & 12.5 & 84.4 \\
$43-51$ & 43 & 11.4 & 95.8 \\
$52-61$ & 16 & 4.2 & 100.0 \\
Total & 377 & 100.0 & \\
\hline
\end{tabular}


As seen in Table 2, most respondents (48.5\%) are from 16-24 age group. This was done on purpose, considering that most heavy users of the smart phones are teenagers and young adults. Yet, for the other age groups, more even distribution was achieved.

Another demographic property of the sample group is about the education distribution, which can be seen below (Table 3):

Table 3: Distribution of education level of respondents

\begin{tabular}{cccc}
\hline Education Level & Frequency & $\%$ & Cum. \% \\
\hline$<$ High school & 18 & 4.8 & 4.8 \\
High school & 74 & 19.6 & 24.4 \\
Vocational school & 22 & 5.8 & 30.2 \\
Bachelor's degree & 203 & 53.8 & 84.1 \\
Graduate degree & 60 & 15.9 & 100.0 \\
Total & 377 & 100.0 & \\
\hline
\end{tabular}

As seen in the table above, 53.8\% of the respondents hold a bachelor's degree, which creates a heterogeneity in the sample. The heterogeneity, can be accepted as one of the most important source of sampling error (Blumberg, Cooper and Schindler, 2005). However, the analysis carried out is not related deeply with the demographics of the respondents, therefore this fact is neglected and the sample is accepted for analysis.)

The survey had a total of 12 components. The Cronbach Alpha (reliability index) for the survey is calculated as .821 , which is at an acceptable level, since the required level of this index is above .70 in social sciences (Nunnaly, 1978).

According to the confirmatory factor analysis results, it is seen that the proposed model is significant at $95 \%$ confidence level, has a high goodness of fit (GFI $=.93$ ) and has an acceptable level of root mean square error (RMSEA $=.07)$.

The goodness of fit indices are shown in the table below (Table 4), with the accepted level and the results of this study:

Table 4: Goodness of Fit Indices of the study and acceptable and good fit levels of the indices

\begin{tabular}{llll}
\hline Indices & $\begin{array}{l}\text { Results Of The } \\
\text { Study }\end{array}$ & Good Fit & Acceptable Fit \\
\hline $\begin{array}{l}\text { Chi-Square } \\
\left(\chi^{2}\right)\end{array}$ & $215.14(\mathrm{p}=0.0)$ & -- & -- \\
RMSEA & 0.073 & $0<\mathrm{RMSEA}<0.05$ & $0.05<\mathrm{RMSEA}<0.10$ \\
NFI & 0.84 & $0.95 \leq \mathrm{NFI} \leq 1.00$ & $0.90 \leq \mathrm{NFI}<0.95$ \\
CFI & 0.89 & $0.97 \leq \mathrm{CFI} \leq 1.00$ & $0.95 \leq \mathrm{CFI}<0.97$ \\
GFI & 0.93 & $0.95 \leq \mathrm{GFI} \leq 1.00$ & $0.90 \leq \mathrm{GFI}<0.95$ \\
AGFI & 0.89 & $0.90 \leq \mathrm{AGFI} \leq 1.00$ & $0.85 \leq \mathrm{AGFI} \leq 0.90$ \\
\hline
\end{tabular}

According to the results of the analysis, the chi-square is calculated as $215.14(\mathrm{p}=$ .00 ), and the degree of freedom is less than 5. This result is the first sign for the goodness fit of the model. The other indices, like root mean square of error of 
approximation (RMSEA) is less than 0.10 , goodness of fit (GFI) index is larger than 0.90 and adjusted goodness of fit AGFI) is larger than 0.85 are the other signs of good fit of the model. However, within the goodness of fit indices, normed fit index (NFI) and comparative fit index (CFI) fall slightly below the acceptable level. This constitutes a shortcoming of the study. Yet, in overall it can be said that the goodness of fit indices of the study fall mostly to the acceptable fit levels. Therefore, the hypothesis tested in the study, suggesting that "customer equity term has 5 components, namely value equity, brand equity, relationship equity, behavioral loyalty and attitudinal loyalty" cannot be rejected.

Moreover, when looked at the resulting paths, a correlation between value equity and brand equity terms is observed (Figure 3). This formation can be tested with a different product and if possible with a random sample of respondents in future studies. The resulting model and the relations in between the constructs can be seen in the figure below (Figure 3):

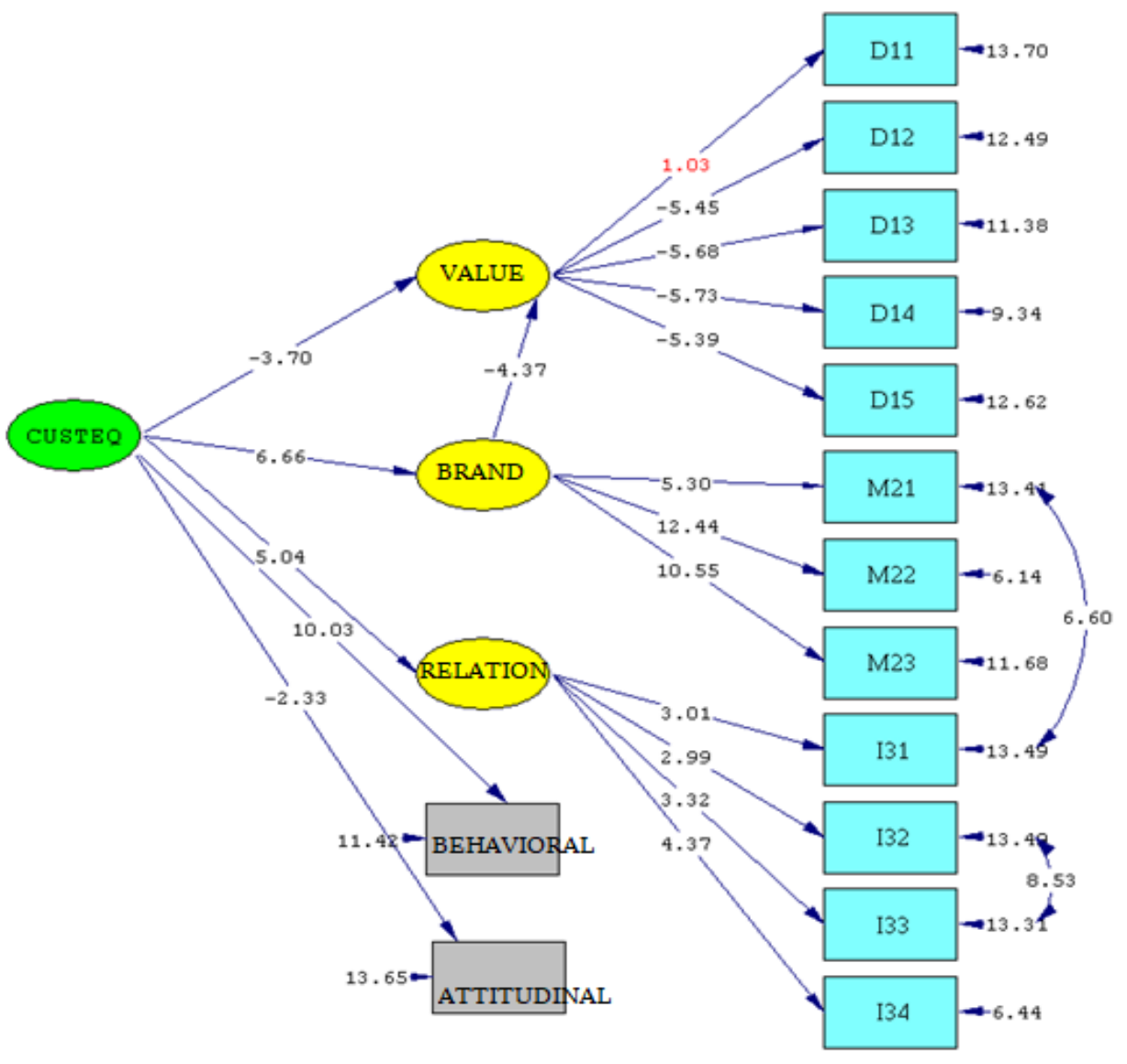

Chi-Square $=212.62, d f=71, P-v a l u e=0.00000$, RMSEA $=0.073$

Figure 3: LISREL output of the modified model and construct relations 


\section{Conclusion}

The Customer Equity (CE) approach to marketing has become a significant research topic during the recent past (Bayon, Gutsche, and Bauer, 2002; Hansotia, 2004; Kumar and Vankatesan, 2005; Rust, Lemon, and Zeithaml, 2004; Wiesel, Skiera, and Villanueva, 2008)

In an attempt to test an alternative model for customer equity, two additional latent variables were added to the original model, which had value equity, brand equity and relationship equity as the components of customer equity. To test the alternative model, data was gathered from a survey with 377 respondents, who are selected on the basis of judgment.

The results of the confirmatory factor analysis with LISREL software shows that, the proposed model with 5 latent variables, namely value equity, brand equity, relationship equity, attitudinal loyalty and behavioral loyalty, are the components of customer equity term.

Moreover, according to the path graph of the analysis, it is seen that there is a significant correlation between value equity and brand equity terms. This result is not surprising because it is known that in products where technical expertise or more involvement is required, customers perceive the brand name as a clue for quality. In this research, the used product was smart phones and it is seen that, the brand name directly affected the quality perception- which is a component of the value equity.

\section{Limitations and Suggestions for further research}

As in any study, this study has also some limitations. Selection of sample can be seen as the first limitation. The sample selection was based on non-probability sampling methods, more specifically, based on judgments. Application of this method created advantage in data gathering, however, as seen in the demographics of the respondents, there exists a heterogeneity among respondents.

Another limitation in the study is in application of survey method as the only data gathering method and not being able to ask detailed questions in the questionnaire are the most important limitations. In future studies, the same study can be applied with combining survey method with in-depth interviews or using a more homogeneous product than smart phones. 


\section{References}

Aaker, D.A. (1992). The Value of Brand Equity, Journal of Business Strategy, 13, (4), 27-32.

Aaker, D.A. (1996). Measuring Brand Equity Across Products and Markets. California Management Review, 38, (3), 102-120.

Baloğlu, S. (2002) Dimensions of Customer Loyalty: Separating Friends from Well Wishers. Cornell Hotel and Restaurant Administration Quarterly,43, (1), 47-59.

Bayon, T., Gutsche, J., and Bauer, H., (2002), Customer Equity Marketing: Touching the Intangible, European Management Journal, 20 (3), 213-222

Bell, D., Deighton, J., Reinartz, W.J., Rust, R.T., Swartz, G. (2002), Seven Barriers to Customer Equity Management. Journal of Service Research, 5, (1), August, 77-86

Berger, P. D., Bolton, R.N., Bowman, D., Briggs, E., Kumar, V., Parasuraman, A. Terry, C. (2002) Marketing Actions and the Value of Customer Assets, Journal of Service Research, 5 (1), 39-54

Berger, P., Nasr, N. (1998), Customer Lifetime Value: Marketing Models and Applications, Journal of Interactive Marketing, 12, Winter (1), 17-30

Blattberg, R., Deighton, J. (1996) Manage Marketing by Customer Equity Test. Harvard Business Review, 136-144

Blattberg, R.C. Getz, G. Thomas, J.S. (2001), Customer Equity: Building and Managing Relationships as Valuable Assets. Harvard Business School Publishing, USA

Blumberg, B., Cooper, D. R., Schindler, P.S. (2005). Business Research Methods, McGraw-Hill, London

Bowen, J.T., Chen, S.L. (2001). The Relationship Between Customer Loyalty and Customer Satisfaction. International Journal of Contemporary Hospitality Management, 13, (5), 213-217

Brocco, A. (2004). Customer Equity: Managing the Customer As an Asset and Cornerstones of Customer Equity. Aktaran: Altıntaş, H. (2006). Müşteri Sermayesi Yönetimi. Alfa Yayınevi

Chang, Y.,Chen, F.Y. (2006). Relational Benefits, Switching Barriers And Loyalty: A Study Of Airline Customers In Taiwan. Journal of Air Transport Management, www.elsevier.com/locate/jairtraman

Day, G.S. (1969) A Two-Dimensional Concept Of Brand Loyalty. Journal of Advertising Research 9, (3), 29-35

Değermen, H.A. (2006) Hizmet Ürünlerinde Kalite, Müssteri Tatmini ve Sadakati (Hizmet Kalitesi Ille Müşteri Sadakatinin Sağlanması ve GSM Sektöründe Bir Uygulama). Türkmen Kitabevi, İstanbul

Dick, A. S., Basu, K. (1994). Customer Loyalty: Toward an Integrated Conceptual Framework. Journal of the Academy of Marketing Science, 22, (2), 99-113

Dorsch, M., Carlson, L., Raymond, M., and Ranson, R. (2001). Customer Equity Management and Strategic Choices for Sales Managers. Journal of Personal Selling and Sales Management, 21, 157-166

Dwyer, F.R. (1997). Customer Lifetime Valuation to Support Marketing Decision Making. Journal of Direct Marketing, 11, (4), 6-13

Dwyer, F.R., Schurr, P.H., Oh, S. (1987). Developing Buyer-Seller Relationships. Journal of Marketing, 51, (2), 11-27

Fruchter, G.E., Zhang, Z.H. (2004). Dynamic Targeted Promotions: A Customer Retention and Acquisition Perspective. Journal of Service Research, 7, (1), 3-19 
Graeff, T.R. (1996). Using promotional messages to manage the Effects of Brand and Self-image on Brand Evaluations. Journal of Consumer Marketing, 13, (3), 4-18

Hansotia, B. (2004). Customer metrics and Organizational Alignment for Maximizing Customer Equity. Database Marketing and Customer Strategy Management, 12, (1), 9-20.

Hoekstra, J.C., Leeflang, P.S.H., Wittink, D.R. (1999), The Customer Concept: The Basis for a New Marketing Paradigm. Journal of Market Focused Management, 4, 43-75

Hogan, J. E., Lemon, K. N., and Rust R. T. (2002). Customer Equity Management: Charting New Directions for the Future of Marketing. Journal of Service Research, 5, 26-38.

Jacoby, H., Kryner, D.B. (1973). Brand loyalty vs. Repeat Purchasing Behaviour. Journal of Marketing Research, 10, 1-9

Jain, D., Singh, S.S (2002). Customer Lifetime Value Research In Marketing: A Review And Future Directions. Journal Of Interactive Marketing, 16, (2), 34-46

Keiningham,T. L., Vavra, T.G., Aksoy, L., Wallard, H. (2006). Sadakat Söylenceleri. Rota Yayıncılık, İstanbul.

Keller, K.L., (2001). Building Customer-Based Brand Equity. Marketing Management. 10(2), 14-19.

Kim, K.J., Jeung, I.J, Cheol-Park, J., Park, Y.J., Kim, C.G., Kim, T.H. (2007). The Impact Of Network Service Performance On Customer Satisfaction And Loyalty: High-Speed Internet Service Case In Korea”, Expert Systems with Applications, 32, (3) 822-831.

Kim, M., Park, M., Jeong, D. (2004). The Effects of Customer Satisfaction And Switching Barrier On Customer Loyalty in Korean Mobile Telecommunication Services. Telecommunications Policy. 28, (2), 145-159.

Kumar, V., Lemon, K.N., Parasuraman, A. (2006). Managing Customers for Value. Journal of Service Research, 9, (2), 87-94

Kumar, V., Venkatesan, R., (2005). Who Are The Multichannel Shoppers And How Do They Perform?: Correlates Of Multichannel Shopping Behavior. Journal of Interactive Marketing, 19, (2), 49-62

Leone, R.P., Rao, V.R., Keller, K.L., Luo, A.M., McAlister, L., Srivastava, R. (2006). Linking Brand Equity to Customer Equity. Journal of Service Research, 9, (2), $125-138$

Leuthesser, L., Kohli, C.S., Harich, K.R. (1995). Brand Equity: The Halo Effect Measure. European Journal of Marketing, 29, (4), 57 - 66

Mellens, M., Dekimpe, M.G., Steenkamp, J.B.E.M. (1996). A Review of Brand Loyalty Measures in Marketing. Tijdschrift voor Economie en Management, 12, (4), 507533.

Mulhern, F. J. (1999), Customer profitability analysis: Measurement, concentration, and research directions. J. Interactive Marketing, 13,25-40

Nunnally, J.C. (1978). Psychometric Theory (2nd ed.), McGraw-Hill, New York, NY

Peppers, D., Rogers, M. (2005). Return On Customer: Creating Maximum Value From Your Scarcest Resource, Broadway Boks

Pfeifer, P. E., Carraway, R. L. (2000). Modeling Customer Relationships as Markov Chains. Journal of Interactive Marketing, 14, (2), 43-55

Pfeifer, P.E., Bang, H., (2005). Non-Parametric Estimation Of Mean Customer Lifetime Value. Journal of Interactive Marketing 19, (4), 48-66 
Reinartz, W., Kumar, V. (2002). The Mismanagement of Customer Loyalty. Harvard Business Review, July, 86-94

Reinartz, W., Kumar, V. (2003). The Impact of Customer Relationship Characteristics on Profitable Lifetime Duration. Journal of Marketing, 67 77-99

Rust, R. T., Verhoef, P. (2005). Optimizing the Marketing Interventions Mix in Intermediate-Term CRM. Marketing Science, 24(3), 477-489

Rust, R.T., Lemon, K.N, Zeithaml, V.A.,. (2005). Measuring Customer Equity and Calculating Marketing ROI. White paper http://www.sagepub.com/refbooksProdTOC.nav?prodId=Book227213andcurrTre $\mathrm{e}=$ Coursesandlevel1=Course11 (Retrieved on: Temmuz 2007)

Rust, R.T., Lemon, K.N., Narayandas, D. (2004- a). Customer Equity Management. Pearson Publishing, New Jersey

Rust, R.T., Zeithaml, V.A., Lemon, K.N. (2000). Driving Customer Equity: How Customer Lifetime Value Is Reshaping Corporate Strategy. The Free Press, New York

Rust, R.T., Zeithaml, V.A., Lemon, K.N. (2004- b). Customer Centered Brand Management. Harvard Business Review, 110- 118

Srinivasan, V., Park, C. S., Chang, D.R. (2005). An Approach to the Measurement, Analysis, and Prediction of Brand Equity and Its Sources. Management Science, 51, (9), 1433-1448

Storbacka K., Strandvik, T., Grönroos C. (1994). Managing Customer Relationships for Profit: The Dynamics of Relationship Quality. International Journal of Service Industry Management, 5, (5), 21-38

Thomas, J. S., Reinartz, W.J., Kumar, V. (2004). Getting The Most Out Of All Your Customers. Harvard Business Review, 82 (7-8), 116-123

Thomas, J., Blattberg, R., Fox, E. (2004). Recapturing Lost Customers. Journal of Marketing Research, 38(2), 31-45.

Villanueva,J. Hanssens, D.M (2007). Customer Equity: Measurement, Management and Research Opportunities. Foundations and Trends in Marketing, 1,(1),1-95

Wiesel, T., Skiera, B., and Villanueva, J. (2008). Customer equity: an integral part of financial reporting. Journal of Marketing, 72, 1-14

Yi, Y. Jeon, H. (2003). Effects of Loyalty Programs on Value Perception, Program Loyalty and Brand Loyalty. Journal of the Academy of Marketing Science, 31, (3), 229- 240

Zeithaml, V., Bitner, M.J. (1996). Services Marketing. McGraw-Hill, New York, N.Y 